\title{
North Atlantic deep water formation and AMOC in CMIP5 models
}

\author{
Céline Heuzé \\ Department of Marine Sciences, University of Gothenburg, Box 115, 40530 Göteborg, Sweden \\ Correspondence to: Céline Heuzé (celine.heuze@ marine.gu.se)
}

Received: 18 January 2017 - Discussion started: 13 February 2017

Revised: 9 May 2017 - Accepted: 2 June 2017 - Published: 26 July 2017

\begin{abstract}
Deep water formation in climate models is indicative of their ability to simulate future ocean circulation, carbon and heat uptake, and sea level rise. Present-day temperature, salinity, sea ice concentration and ocean transport in the North Atlantic subpolar gyre and Nordic Seas from 23 CMIP5 (Climate Model Intercomparison Project, phase 5) models are compared with observations to assess the biases, causes and consequences of North Atlantic deep convection in models. The majority of models convect too deep, over too large an area, too often and too far south. Deep convection occurs at the sea ice edge and is most realistic in models with accurate sea ice extent, mostly those using the CICE model. Half of the models convect in response to local cooling or salinification of the surface waters; only a third have a dynamic relationship between freshwater coming from the Arctic and deep convection. The models with the most intense deep convection have the warmest deep waters, due to a redistribution of heat through the water column. For the majority of models, the variability of the Atlantic Meridional Overturning Circulation (AMOC) is explained by the volumes of deep water produced in the subpolar gyre and Nordic Seas up to 2 years before. In turn, models with the strongest AMOC have the largest heat export to the Arctic. Understanding the dynamical drivers of deep convection and AMOC in models is hence key to realistically forecasting Arctic oceanic warming and its consequences for the global ocean circulation, cryosphere and marine life.
\end{abstract}

\section{Introduction}

Global fully coupled climate models are a key tool to study current and future climate change, but although they clearly improve from one generation to the next, they still suffer from many biases (Flato et al., 2013). In particular the hor- izontal resolution of the ocean, around $1^{\circ}$ (Table 1), is too coarse for explicitly representing eddies, freshwater plumes and overflows. Yet all these processes are necessary to correctly generate deep water formation (Marshall and Schott, 1999).

Deep water formation occurs around Antarctica and in the North Atlantic (Killworth, 1983). It is vital for ventilation of the ocean and for the global ocean circulation, but also for heat and carbon storage (e.g. Sabine et al., 2004; Lozier et al., 2008; Schmittner and Lund, 2015). Moreover, in the North Atlantic, deep water formation is tied to the strength of the Atlantic Meridional Overturning Circulation (AMOC, Böning et al., 2006), which transports heat to the Arctic (Spielhagen et al., 2011). This oceanic heat in turn melts the sea ice and Greenland floating glaciers from below (e.g. Polyakov et al., 2010; Straneo and Heimbach, 2013). Hence, the North Atlantic is a crucial area to assess the ability of currentgeneration climate models to represent deep water formation.

In this paper, we compare present-day deep water formation in 23 state-of-the-art global climate models that participated in the Climate Model Intercomparison Project phase 5 (CMIP5, Taylor et al., 2012). We assess their biases in the representation of deep convection in Sect. 3, explore the possible causes of these biases in Sect. 4, notably buoyancy forcings and sea ice, and estimate the consequences of their biases on the AMOC and heat export to the Arctic in Sect. 5. To the best of our knowledge, similar tests have been done on the previous generation of climate models (CMIP3, de Jong et al., 2009) and in ocean-only simulations (CORE-II, Danabasoglu et al., 2014), but not yet on CMIP5 models. Yet the magnitude of biases in CMIP5 models has to be known in order to properly simulate changes to the Arctic using the current generation of models, and also to evaluate improvements when CMIP6 model simulations become available (Eyring et al., 2016). 
Table 1. List of CMIP5 models (Taylor et al., 2012): modelling groups, model names, ocean resolution in the North Atlantic (longitude/latitude/number of depth levels), type of vertical grid in the ocean ( $z$ is geopotential, $z^{*}$ is geopotential with free sea surface, $\sigma$ is terrain following, $\sigma_{2}$ is isopycnic, and $\mathrm{H}$ denotes an hybrid grid), and sea ice component. Stars * indicate the models whose pre-industrial control run is used in Sect. 5.2.

\begin{tabular}{|c|c|c|c|c|}
\hline Modelling group & Model name & $\begin{array}{l}\text { Resolution } \\
(x / y / L)\end{array}$ & Grid & Sea ice model \\
\hline $\begin{array}{l}\text { CSIRO and Bureau of Meteorology, } \\
\text { Australia }\end{array}$ & ACCESS1-0 & $1^{\circ} / 1^{\circ} / 50$ & $z$ & CICE v4 \\
\hline $\begin{array}{l}\text { Beijing Climate Center, China } \\
\text { Meteorological Administration }\end{array}$ & bcc-csm1-1* & $1^{\circ} / 1^{\circ} / 40$ & $z$ & SIS \\
\hline $\begin{array}{l}\text { Canadian Centre for Climate Mod- } \\
\text { elling } \\
\text { and Analysis }\end{array}$ & CanESM2* & $1.5^{\circ} / 1.5^{\circ} / 40$ & $z$ & CanSIM1 \\
\hline $\begin{array}{l}\text { National Center for Atmospheric } \\
\text { Research }\end{array}$ & $\begin{array}{l}\text { CCSM4 } \\
\text { CESM1-CAM5 }\end{array}$ & $\begin{array}{l}1^{\circ} / 0.5^{\circ} / 60 \\
1^{\circ} / 0.5^{\circ} / 60\end{array}$ & $\begin{array}{l}z \\
z\end{array}$ & $\begin{array}{l}\text { CICE v4 } \\
\text { CICE v4 }\end{array}$ \\
\hline $\begin{array}{l}\text { Centro Euro-Mediterraneo sui } \\
\text { Cambiamenti Climatici }\end{array}$ & $\begin{array}{l}\text { CMCC-CM } \\
\text { CMCC-CMS }\end{array}$ & $\begin{array}{l}2^{\circ} / 2^{\circ} / 31 \\
2^{\circ} / 2^{\circ} / 31\end{array}$ & $\begin{array}{l}z \\
z\end{array}$ & $\begin{array}{l}\text { LIM2 } \\
\text { LIM2 }\end{array}$ \\
\hline $\begin{array}{l}\text { Centre National de Recherches } \\
\text { Météorologiques/Centre Européen de } \\
\text { Recherche et Formation Avancée en } \\
\text { Calcul Scientifique }\end{array}$ & CNRM-CM5A* & $0.7^{\circ} / 0.7^{\circ} / 42$ & $z$ & GELATO v5 \\
\hline $\begin{array}{l}\text { CSIRO and Queensland Climate } \\
\text { Change Centre of Excellence }\end{array}$ & CSIRO-Mk3-6-0* & $1.8^{\circ} / 0.9^{\circ} / 31$ & $z$ & Component of Mk3 \\
\hline $\begin{array}{l}\text { LASG, Institute of Atmospheric } \\
\text { Physics, Chinese Academy of Sciences } \\
\text { and CESS, Tsinghua University }\end{array}$ & FGOALS-g2 & $1^{\circ} / 1^{\circ} / 30$ & $z^{*}$ & CICE v4 \\
\hline $\begin{array}{l}\text { NOAA Geophysical Fluid Dynamics } \\
\text { Laboratory }\end{array}$ & $\begin{array}{l}\text { GFDL-CM3 } \\
\text { GFDL-ESM2G* } \\
\text { GFDL-ESM2M* }\end{array}$ & $\begin{array}{l}1^{\circ} / 1^{\circ} / 50 \\
1^{\circ} / 1^{\circ} / 63 \\
1^{\circ} / 1^{\circ} / 50\end{array}$ & $\begin{array}{l}z^{*} \\
\sigma_{2} \\
z^{*}\end{array}$ & $\begin{array}{l}\text { SISp2 } \\
\text { SISp2 } \\
\text { SISp2 }\end{array}$ \\
\hline $\begin{array}{l}\text { NASA Goddard Institute for Space } \\
\text { Studies }\end{array}$ & GISS-E2-R* & $1.25^{\circ} / 1^{\circ} / 32$ & $z^{*}$ & Russell sea ice \\
\hline Met Office Hadley Centre & $\begin{array}{l}\text { HadGEM2-CC* } \\
\text { HadGEM2-ES* }\end{array}$ & $\begin{array}{l}1 \% / 1^{\circ} / 40 \\
1 \% / 1^{\circ} / 40\end{array}$ & $\begin{array}{l}z \\
z\end{array}$ & $\begin{array}{l}\text { based on CICE } \\
\text { based on CICE }\end{array}$ \\
\hline Institut Pierre-Simon Laplace & $\begin{array}{l}\text { IPSL-CM5A-LR* } \\
\text { IPSL-CM5A-MR* }\end{array}$ & $\begin{array}{l}2^{\circ} / 2^{\circ} / 31 \\
2^{\circ} / 2^{\circ} / 31 \\
\end{array}$ & $\begin{array}{l}z \\
z\end{array}$ & $\begin{array}{l}\text { LIM2 } \\
\text { LIM2 }\end{array}$ \\
\hline $\begin{array}{l}\text { JAMSTEC Atmosphere and Ocean Re- } \\
\text { search Institute (The University of } \\
\text { Tokyo), and National Institute for En- } \\
\text { vironmental Studies }\end{array}$ & $\begin{array}{l}\text { MIROC5* } \\
\text { MIROC-ESM-CHEM* }\end{array}$ & $\begin{array}{l}0.5^{\circ} / 0.5^{\circ} / 50 \\
1.4^{\circ} / 1.4^{\circ} / 44\end{array}$ & $\begin{array}{l}\mathrm{H} \sigma-z \\
\mathrm{H} \sigma-z\end{array}$ & $\begin{array}{l}\text { Component of } \\
\text { COCO3.4 } \\
\text { Component of } \\
\text { COCO3.4 }\end{array}$ \\
\hline Max-Planck-Institut für Meteorologie & $\begin{array}{l}\text { MPI-ESM-LR* } \\
\text { MPI-ESM-MR }\end{array}$ & $\begin{array}{l}1.5^{\circ} / 1.5^{\circ} / 40 \\
0.4^{\circ} / 1.5^{\circ} / 40\end{array}$ & $\begin{array}{l}z \\
z\end{array}$ & $\begin{array}{l}\text { Component of } \\
\text { MPI-OM } \\
\text { Component of } \\
\text { MPI-OM }\end{array}$ \\
\hline Norwegian Climate Centre & NorESM1-M & $1.125^{\circ} / 1.125^{\circ} / 53$ & $\mathrm{H} \sigma_{2}-z$ & CICE v4 \\
\hline
\end{tabular}




\section{Data and methods}

\subsection{CMIP5 models}

The output of 23 CMIP5 models (Taylor et al., 2012), listed in Table 1, were used in this study. In the North Atlantic, all models have approximately the same horizontal grid spacing, varying around $1^{\circ}$ in both latitude and longitude. The coarsest resolution is $2^{\circ}$ (for the CMCC models) and the highest is $0.4^{\circ}$ (for MPI-ESM-MR). Most models have a $z$-level vertical grid with an average of 40 levels (Table 1). Although four models were run on a different type of grid (isopycnic, terrain following or hybrid), their output were submitted on a regular $z$-level grid.

In this study, 15 models use only three different sea ice components (Table 1): the Los Alamos sea ice model (CICE; Hunke and Lipscomb, 2008), the GFDL sea ice simulator (SIS; Delworth et al., 2006) and the Louvain-la-Neuve sea ice model (LIM; Fichefet and Maqueda, 1997). The other climate models mostly use the sea ice component of their respective ocean models. Although each climate model has a unique configuration, comparing models which share components - as we do in Sect. 4.2 - can indicate what causes a misrepresentation.

We are interested in the mean, present state of the ocean and hence use 20 years of monthly historical run from January 1986 to the end of the historical run in December 2005. The monthly pre-industrial control run was used to remove possible model drift. We also use the control run from 1986 to 2100 to study lagged correlations in a subset of 14 models for which such long runs were available (indicated with a star in Table 1); see Sect. 5.2. Only one ensemble member per model was used, r1i1p1, for it was the only one common to all the models at the date of download (July 2016).

\subsection{Observational-based products}

Three observational-based analysis products are used for assessing the models' representation of the present-day ocean. They are not the most recent climatologies, but have been chosen as representative of the 1986-2005 period studied here with the climate models. The observed monthly climatology of mixed layer depth (MLD) is that of de Boyer Montégut et al. (2004), available at http://www.ifremer.fr/cerweb/ deboyer/mld/home.php. It was created using a density criterion of $0.03 \mathrm{~kg} \mathrm{~m}^{-3}$ over more than 4 million hydrographic profiles, taken from 1941 to 2002, interpolated onto a regular $2^{\circ} \times 2^{\circ}$ horizontal grid.

The temperature and salinity of the observed water column are given by the World Ocean Atlas 2009 (WOA09, Locarnini et al., 2013; Zweng et al., 2013, http://www.nodc. noaa.gov/OC5/WOA09/pr_woa09.html). It includes over 9 million quality-controlled hydrographic profiles. The monthly climatology is limited to the top $1500 \mathrm{~m}$ of the ocean, and hence the seasonal climatology is used here. It is provided as a regular $1^{\circ} \times 1^{\circ} \times 33$ level grid.

Finally, we use the HadISST monthly sea ice concentration measurements (Rayner et al., 2003, http://www. metoffice.gov.uk/hadobs/hadisst/), from January 1986 to December 2005, also provided as a regular $1^{\circ} \times 1^{\circ}$ grid. The observed sea ice extent is computed as the sum of the areas of the grid cells with a sea ice concentration larger than $15 \%$. To facilitate comparisons, the model output have been interpolated onto the common HadISST-WOA09 grid.

\subsection{Methods}

Some climate models provide a mixed layer depth output, but not the majority of them. For consistency amongst models and with the observations, we instead compute the monthly MLD for each model using the de Boyer Montégut et al (2004) method. That is, using the monthly temperature and salinity model output to compute the density $\sigma_{\theta}$, we define the MLD as the depth where the density exceeds that of the reference level $(10 \mathrm{~m})$ by $0.03 \mathrm{~kg} \mathrm{~m}^{-3}$.

Following observations, we consider that there is deep water formation or deep convection if the MLD exceeds $1000 \mathrm{~m}$ (e.g. Marshall and Schott, 1999; Våge et al., 2009). We divide the North Atlantic into two study areas where in the real ocean different deep waters form (Killworth, 1983): the Greenland-Iceland-Norwegian (GIN) seas (latitude 66$80^{\circ} \mathrm{N}$, longitude $20^{\circ} \mathrm{W}$ to $20^{\circ} \mathrm{E}$ ) and the subpolar gyre ( $\mathrm{SG}$, latitude $50-65^{\circ} \mathrm{N}$, longitude $65-20^{\circ} \mathrm{W}$; see orange boxes in Fig. 1a). The volume of deep water formed by each model is defined as the product of the grid cell area by the MLD, summed over all the grid cells with a MLD deeper than $1000 \mathrm{~m}$ in each of these two regions.

One of the buoyancy forcings whose impact on deep convection we study is the freshwater flux from the Arctic through the two sections closest to SG and GIN: the Davis and Fram straits, respectively. Following, for instance, Aagaard and Carmack (1989) these are computed as follow:

$\mathrm{FW}=\int_{A}\left(1-S / S_{\mathrm{ref}}\right) v \mathrm{~d} A$,

where $S_{\text {ref }}=34.8$ is a reference salinity, $S$ is the monthly salinity field, $v$ is the meridional velocity field, and $A$ is the corresponding depth-longitude section. The coordinates considered for the Davis Strait are $66^{\circ} \mathrm{N}, 70-50^{\circ} \mathrm{W}$; for the Fram Strait, $80^{\circ} \mathrm{N}$ and $20-15^{\circ} \mathrm{E}$ (cyan lines in Fig. 1a). Similarly, the heat flux through the Fram Strait was computed as follows:

$Q=\int_{A} \rho_{0} c_{p} \theta v \mathrm{~d} A$,

where $\rho_{0}=1027 \mathrm{~kg} \mathrm{~m}^{-3}$ is a reference density of water, $c_{p}=3.98 \mathrm{~kJ} \mathrm{~kg} \mathrm{~K}^{-1}$ is the specific heat capacity of water, 
(a) Clim. obs.

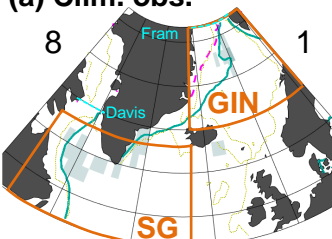

(e) CCSM4 (b) ACCESS1-0 (c) BCC-CSM1-1 (d) CanESM2

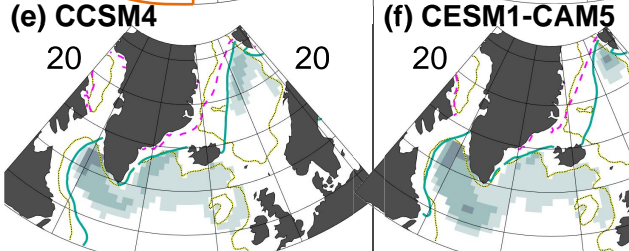

(i) CNRM-CM5

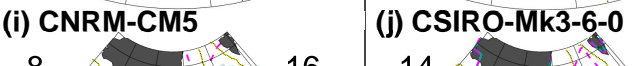

(j) CSIRO-Mk3-6-0

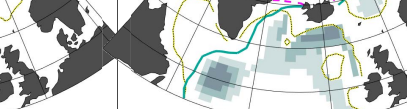

(k) FGOALS-g2 (g) CMCC-CM

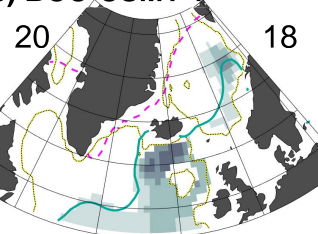

.

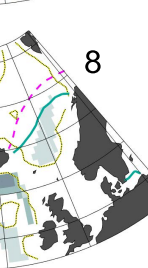

(I) GFDL-CM3

(h) CMCC-CMS
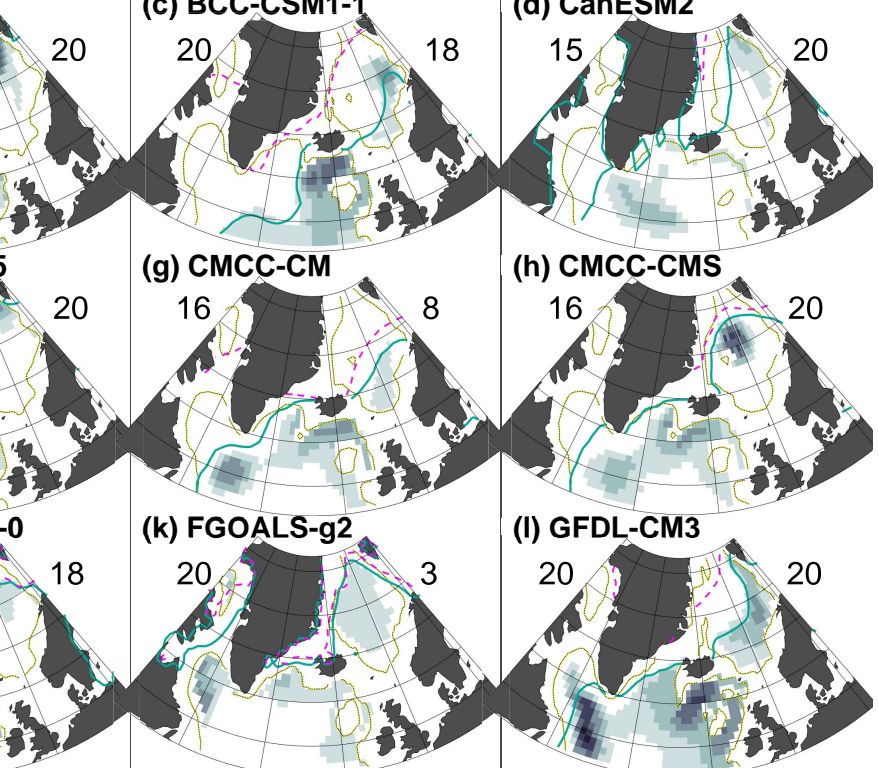

(3)

(n) GFDL-ESM2M

(m) GFDL-ESM2G

3,1

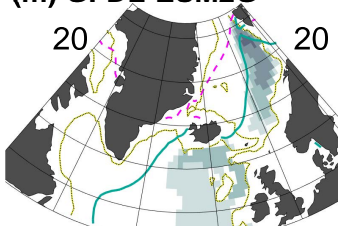

3.

(q) HadGEM2-ES
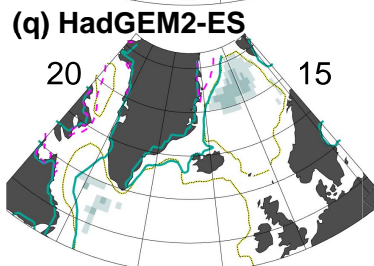

(r) IPSL-CM5A-LR

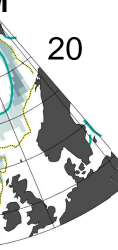

(o) GISS-E2-R

(p) HadGEM2-CC

(u) MIROC-ESM-CHEM

(v) MPI-ESM-LR

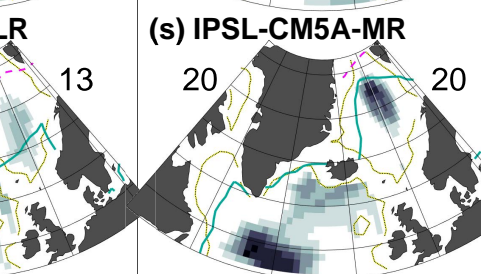

(s) IPSL-CM5A-MR

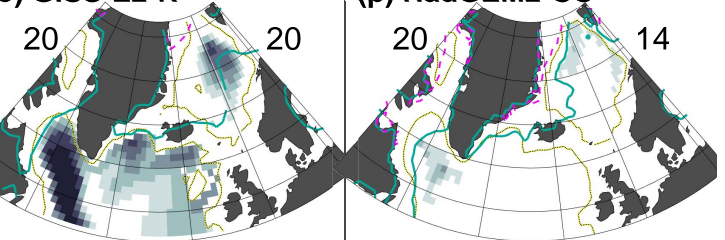

(t) MIROC5

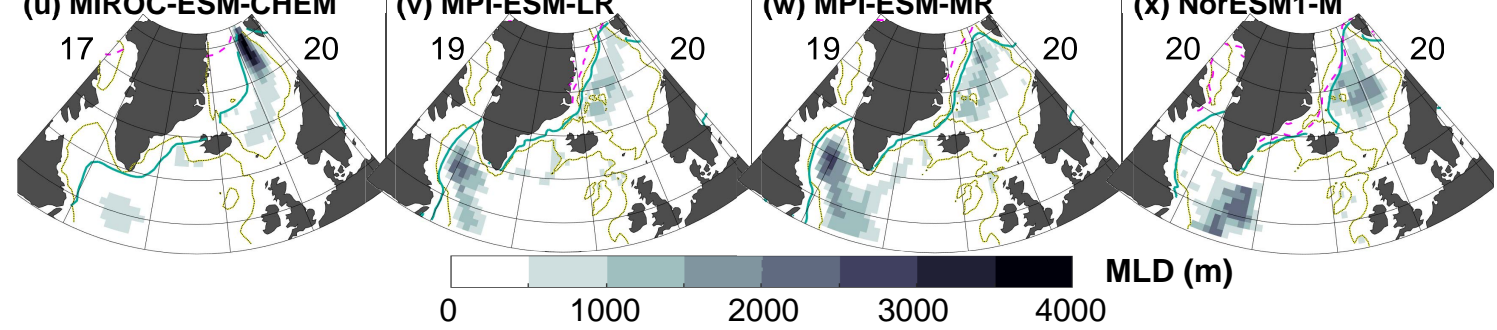

Figure 1. North Atlantic (a) climatological mixed layer depth of de Boyer Montégut et al. (2004) and (b-x) mean 1986-2005 winter MLD in the CMIP5 historical run. Orange boxes on (a) show the subpolar gyre (SG) and Greenland-Iceland-Norwegian (GIN) seas regions as defined in this study; cyan dashed lines are the Davis and Fram straits. Yellow dotted line on each panel indicates the $1000 \mathrm{~m}$ isobath; blueish green and magenta lines denote the mean March and September sea ice extent, respectively. Left number is the number of years, out of 20, with deep convection in SG; right number is deep convection in GIN.

and $\theta$ is the monthly temperature field. The other buoyancy forcings that are studied here are the local heat and salt changes by interaction with the atmosphere. These are defined as the month-to-month difference in heat and salt content, respectively, from the ocean surface to the MLD.
To assess the consequences of deep water formation, we study the hydrographic properties averaged over the same two depth ranges as de Jong et al. (2009):

- the Labrador Sea Water (LSW) layer, $750-1250 \mathrm{~m}$ depth; 
- and the Northeast Atlantic Deep Water (NEADW) layer, 2000-2500 m depth.

We shall refer to water found at these two levels in models as North Atlantic Deep Water (NADW), with no further distinction between LSW and NEADW. We do not attempt to define NADW using temperature, salinity or density criteria as is done in observations (e.g. Weaver et al., 1999), since such criteria are not adapted to models that we expect to feature temperature, salinity or density biases. The monthly AMOC is obtained by integrating the meridional velocity at $30^{\circ} \mathrm{N}$ through the Atlantic basin from coast to coast, and then over depth using the bottom of the ocean as the reference level. The AMOC is defined as the maximum southward transport (Cheng et al., 2013).

\section{The representation of North Atlantic deep water formation in CMIP5 models}

\subsection{Comparison with observations}

Deep convection occurs in the North Atlantic in two main areas: in the subpolar gyre, and in the Greenland-IcelandNorwegian seas (Fig. 1a). It has been measured and found to extend deeper than $2000 \mathrm{~m}$ (Marshall and Schott, 1999), but it does not occur every year in the real ocean. In fact, over the 1986-2005 period of this study, deep convection occurred in the subpolar gyre only from 1987 to 1994 and in winter 1999-2000 (Yashayaev, 2007; Våge et al., 2009); in the GIN seas, only in winter 1988 (Marshall and Schott, 1999). Hence, the climatology made of observations shows relatively shallow mean mixed layers that do not exceed $1000 \mathrm{~m}$ (Fig. 1a). Still, some models are clearly convecting too deep, with MLD reaching from the surface to the sea floor: GFDLCM3, GISS-E2-R, IPSL-CM5A-MR and MPI-ESM-MR in the SG area (Fig. 11, o, s, w) and GISS-E2-R and IPSLCM5A-MR again as well as both MIROC models in the GIN area (Fig. 1o, s, t, u).

Most models exhibit very deep 20-year mean mixed layers, over large areas, and convect in both regions nearly every year. In the SG region, the models can be split into three different groups based on the location of the deep convection centre:

- the models that convect mostly in the Labrador Sea, or northern part of SG: CCSM4, CESM1CAM5, CNRM-CM5, FGOALS-g2, HadGEM2-CC, HadGEM2-ES, MIROC5, MPI-ESM-LR and MPIESM-MR (Fig. 1e, f, i, k, p, q, t, v, w)

- the models that convect too far in the south: ACCESS1-0, bcc-csm1-1, CanESM2, CMCC-CM, CMCC-CMS, GFDL-ESM2G, GFDL-ESM2M, IPSLCM5A-LR, IPSL-CM5A-MR, MIROC-ESM-CHEM, and NorESM1-M (Fig. 1b, c, d, g, h, m, n, r, s, u, x)
- the models that convect everywhere: CSIRO-Mk3-6-0, GFDL-CM3 and GISS-E2-R (Fig. 1j, 1, o)

In fact, in the SG area, 9 out of 23 models convect at the correct location. The majority of models convect at the wrong location, and in particular too far in the south, which is a common feature in climate models (e.g. Treguier et al., 2005; Jungclaus et al., 2005). In both SG and GIN, the location of deep MLD seems constrained by the winter sea ice extent (blue line in Fig. 1); this will be further discussed in Sect. 4.2.

Unlike the real North Atlantic Ocean and its "deep convection seesaw" (Oka et al., 2006), i.e. the alternation between deep convection in SG and in the GIN seas, most models convect in both regions at the same time, every year of the study period. The exceptions are as follows:

- in SG, CanESM2, both CMCCs and CSIRO-Mk36- 0 convect only $75 \%$ of the years (left numbers, Fig. 1d, g, h, j), and CNRM-CM5 less than 50\% (Fig. 1i);

- in GIN, CNRM-CM5 again, both HadGEM2s, and IPSL-CM5A-LR convect $75 \%$ of the years (right numbers, Fig. 1i, p, q, r), and CMCC-CM and FGOALS-g2 less than $50 \%$ (Fig. 1g, k).

No CMIP5 model from this study has a variability similar to that observed in the real North Atlantic during 1986-2005, but two models, CMCC-CM and CNRM-CM5, exhibit more variability, in both seas, than the other models.

A full assessment of the impact of resolution and model code changes is not possible with the limited data used here. In fact, this is the motivation for the CORE-II (Danabasoglu et al., 2014) and upcoming OMIP (Griffies et al., 2016) exercises. It is nonetheless interesting to note how differently models which share components behave. For example, the following was observed:

- CMCC-CM and CMCC-CMS differ only in the configuration of the atmospheric code, yet CMCC-CMS has a far more intense deep convection region in the GIN seas (Fig. 1g, h). HadGEM2-CC and HadGEM2ES also differ only slightly in their atmospheric code (HadGEM2-ES includes tropospheric chemistry), yet their deep convection behaviours are not obviously different (Fig. 1p, q).

- IPSL-CM5-LR and IPSL-CM5-MR differ in the resolution of their common atmospheric component (IPSLCM5-MR is the highest), and the mean MLD is deeper, over a larger area in IPSL-CM5-MR (Fig. 1r, s). In the meantime, although CCSM4 and CESM1-CAM5 also have different atmosphere models but the same ocean code, their deep convection behaviours in both seas are equivalent (Fig. 1e, f). 
- GFDL-ESM2M is more similar to GFDL-ESM2G in deep convection characteristics despite their different ocean components than to GFDL-CM3 whose ocean model code is the same as that of GFDL-ESM2M.

In summary, choices of ocean or atmosphere model codes and resolutions cannot be directly linked to specific deep convection behaviours. All models from this study convect too often, too deep and over too large an area when compared to observations. Nine models are relatively realistic, though, regarding the location of deep convection; among these nine models, four of them (CNRM-CM5, FGOALS-g2, HadGEM2-CC and HadGEM2-ES) also exhibit some temporal variability instead of wrongly convecting each year, and can hence be deemed "the most accurate models".

\subsection{Has deep convection representation improved since CMIP3?}

In a study of eight CMIP3 models, de Jong et al. (2009) found that deep convection was too shallow in the Labrador Sea, while Drijfhout et al. (2008) found deep convection to be too deep, over too large an area in a region corresponding to the southern part of our SG. Half of the models presented some variability in the mean maximum MLD, an indication that they did not convect every year in SG. To the best of our knowledge, no study has assessed the performance of CMIP3 models with respects to MLD in the GIN seas, although the occasional map of this region by Carman and McClean (2011) does show a large spread in maximum depth and area of deep convection among the 10 models of their study.

CMIP5 models have improved compared to their CMIP3 counterparts, since deep convection in the GIN seas is more localised for the majority of them. Out of our sample of 24, 9 models have realistic MLD in the Labrador Sea, at the correct location, and 4 of them even have a realistic variability. Most CMIP5 models also convect less deeply than the CMIP3 models did; most of the models in the present study convect only to $2000 \mathrm{~m}$ on average, whereas most mean CMIP3 MLDs in the subpolar gyre extended to the sea floor.

However, some problems remain. The majority of models in our study convect at the wrong location in the subpolar gyre, too far south and/or over too large an area extending south of Iceland. CMIP5 and CMIP3 models alike convect too often, or rather more often than the real ocean did over the same period. And a minority of CMIP5 models have MLDs that are far too deep.

Why are some of these biases still present in CMIP5 models? Can they be caused by other biases that have not been improved and/or specific model components? We investigate these questions now, in Sect. 4.

\section{Across-model possible causes of deep water formation misrepresentations}

\subsection{Heat and salt}

The aim of the present paper is not to determine the dynamics of deep convection in all the individual CMIP5 models, since that would require access to 100 -to-1000 year simulations (as was done in the Southern Ocean by Martin et al., 2013, for example). Instead, we verify whether specific biases in the models are consistently associated with misrepresentations of deep water formation. We concentrate on features that have been highlighted in observations or in other modelling studies as potential triggers for deep convection: stratification, freshwater import from the Arctic, local buoyancy forcings and sea ice (Marshall and Schott, 1999).

In this section, we concentrate on the buoyancy biases: both freshwater import from the Arctic and local processes. No across-model relationship was found, but rather different behaviours for different models were observed, which are summarised in Table 2. The sign conventions (see Sect. 2.3) are as follows:

- negative for the vertical density gradient (bold font, Table 2) means that the smaller the density gradient, i.e. the less stratified the water column, the deeper the mixed layer;

- negative for "freshwater from Davis or Fram straits" (italic bold font) means that the more freshwater is flowing southward from the Arctic, the less deep convection;

- positive for "Heat loss" or "Salt gain" (italic font) means that the stronger the local surface cooling or salinification, the deeper the convection.

Fourteen models out of 23 show a significant relationship, in the sense one would expect, between the vertical density gradient and deep convection in the subpolar gyre, and thirteen in the GIN seas, but only nine in both regions (Table 2, figures in bold font). This relationship MLD - stratification does not correlate with the model MLD biases. For example, CCSM4 and CESM1-CAM have similar deep convection depth and area in the subpolar gyre (Fig. 1e and f), but only CCSM4 has a significant correlation between MLD and vertical density gradient. Moreover, there is no apparent relationship between stratification, MLD, and the vertical mixing parameterisation. In particular, the parameterisation designed by Fox-Kemper et al. (2011) to improve the mixed layer representation (present in the models marked with a black bullet point, Table 2) does not consistently result in better performances than those models without the parameterisation. This lack of relationship between MLD biases and vertical mixing parameterisation was already found by Huang et al. (2014) for the summer MLD.

Nine models out of 23 show a negative correlation between the freshwater coming from the Arctic via the Davis Strait 
Table 2. For each model, for the subpolar gyre SG (left) and the GIN seas (right), significant correlation (if any) between the time series of the winter mixed layer depth and the local vertical density gradient $\frac{\partial \rho}{\partial z}$, the Arctic freshwater export via Davis (left) or Fram (right) straits, the local heat exchange with the atmosphere and the local surface salinity change. Different font styles highlight correlation that could explain deep water formation in each model. Sign conventions: negative with $\frac{\partial \rho}{\partial z}$ or freshwater means that low stratification or freshwater transport correspond to deep mixed layers; positive correspond to heat loss or salt gain if an ocean surface cooling or salinification corresponds to deep mixed layers. Models featuring the Fox-Kemper et al. (2011) mixed layer parameterisation are indicated by a black bullet after their name.

\begin{tabular}{|c|c|c|c|c|c|c|c|c|}
\hline \multirow[b]{2}{*}{ Model } & \multicolumn{4}{|c|}{ Subpolar gyre (SG) } & \multicolumn{4}{|c|}{ Nordic seas (GIN) } \\
\hline & $\frac{\partial \rho}{\partial z}$ & Davis & Heat loss & Salt gain & $\frac{\partial \rho}{\partial z}$ & Fram & Heat loss & Salt gain \\
\hline ACCESS1-0. & -0.88 & -0.43 & 0.50 & - & - & -0.44 & 0.41 & -0.40 \\
\hline bcc-csm1-1 & -0.51 & 0.54 & 0.51 & 0.43 & $-\mathbf{0 . 8 9}$ & 0.55 & 0.42 & 0.48 \\
\hline CanESM2 & -0.63 & -0.53 & - & -0.43 & -0.73 & - & 0.57 & - \\
\hline CCSM4. & -0.78 & - & 0.84 & - & - & - & 0.62 & -0.51 \\
\hline CESM1-CAM5. & - & 0.51 & 0.49 & - & -0.60 & - & 0.41 & -0.40 \\
\hline CMCC-CM & -0.81 & - & - & - & - & - & - & - \\
\hline CMCC-CMS & -0.59 & - & 0.48 & 0.41 & -0.55 & 0.86 & - & -0.45 \\
\hline CNRM-CM5 & - & -0.85 & - & 0.91 & - & 0.64 & - & - \\
\hline CSIRO-Mk3-6-0 & -0.72 & - & 0.66 & - & -0.70 & - & - & 0.67 \\
\hline FGOALS-g2 & -0.83 & -0.39 & 0.52 & - & - & - & - & - \\
\hline GFDL-CM3 & - & 0.73 & 0.47 & 0.52 & $-\mathbf{0 . 8 3}$ & -0.54 & 0.50 & -0.45 \\
\hline GFDL-ESM2G. & $-\mathbf{0 . 8 1}$ & - & 0.50 & 0.43 & -0.64 & 0.68 & 0.49 & -0.40 \\
\hline GFDL-ESM2M. & -0.59 & - & -0.71 & 0.61 & $-\mathbf{0 . 8 5}$ & -0.55 & 0.75 & -0.74 \\
\hline GISS-E2-R & - & 0.41 & 0.51 & 0.42 & - & 0.55 & -0.39 & -0.45 \\
\hline HadGEM2-CC & -0.59 & -0.55 & 0.48 & - & -0.47 & - & - & - \\
\hline HadGEM2-ES & -0.59 & - & - & 0.41 & -0.73 & - & 0.72 & -0.39 \\
\hline IPSL-CM5A-LR & -0.64 & - & - & - & -0.67 & - & 0.55 & -0.55 \\
\hline IPSL-CM5A-MR & - & 0.46 & -0.48 & 0.70 & -0.74 & - & -0.49 & -0.48 \\
\hline MIROC5 & - & -0.64 & -0.61 & 0.53 & - & 0.51 & - & - \\
\hline MIROC-ESM-CHEM & -0.80 & -0.49 & - & 0.60 & - & - & - & - \\
\hline MPI-ESM-LR & - & -0.40 & -0.43 & 0.55 & - & - & - & 0.62 \\
\hline MPI-ESM-MR & - & -0.48 & - & -0.42 & -0.56 & 0.48 & - & - \\
\hline NorESM1-M & - & 0.45 & -0.69 & - & - & - & -0.49 & -0.51 \\
\hline
\end{tabular}

and the MLD in the subpolar gyre (Table 2, first and fourth columns). For three of these models, CanESM2, MIROCESM-CHEM and MPI-ESM-MR, it is even the only meaningful relationship. In the GIN seas, the negative relationship freshwater from the Arctic - MLD is present in only three models. Note that only one model, ACCESS1-0, has a correlation in both regions. A mysterious positive correlation, i.e. the stronger the freshwater import the deeper the MLD, is found for six models in SG and six models in GIN, with two models common to both regions (bcc-csm1-1 and GISSE2-R). Correlation does not mean causation, so it is possible that in these models MLD and freshwater import are linked to a third process, for example the sea ice extent.

The relationship between local heat loss to the atmosphere and MLD is more consistent: 11 models exhibit a positive correlation in SG, compared to 10 in the GIN seas (Table 2, italicised figures in third and seventh columns). For these models, as is the case in the real ocean (Killworth, 1983), the stronger the surface cooling, the deeper the MLD. For five models (GFDL-ESM2M, IPSL-CM5A-MR, MIROC5, MPI-ESM-LR and NorESM1-M), the opposite relationship is found: deep convection corresponds to a surface heat gain. It could be that in these models, deep convection is triggered so fast that we see its result, the mixing up of subsurface warm water (Marshall and Schott, 1999), when other models are still in the preconditioning phase. Output at a higher temporal resolution than the current monthly data would be required to study this question.

Finally, 12 models have deep MLD in association with a salinification of the surface waters in SG, compared to only 3 in the GIN seas (italicised figures in fourth and last columns of Table 2). In fact in the GIN seas, the opposite relationship is encountered the most often, for 12 of the models. CMCC-CMS also has a positive relationship with the freshwater from the Arctic, suggesting that a more-complex-thanthought freshwater cycle in the GIN seas could be linked to deep convection. For the 11 other models, this negative relationship remains unexplained as monthly outputs are not of a high enough resolution for such a study.

In summary, in the real North Atlantic, deep convection is mainly controlled by local surface buoyancy forcings: heat loss to the atmosphere in SG (Marshall and Schott, 1999), 
and haline convection in the GIN seas (Rudels and Quadfasel, 1991). In CMIP5 models, no consistent behaviour was found. CSIRO-Mk3-6-0 is the only model which seems to have the same drivers of deep convection as the observations, and a clear distinction between the two regions. Half of the models exhibit unexpected relationships, showing that higher-resolution outputs are required to study their dynamics. And five models had no significant correlation; their deep convection hence is probably controlled by something else. We now check if this could be the sea ice.

\subsection{Sea ice}

The link between deep convection and sea ice is evident in the GIN seas, where in the real ocean ice crystals have to form in the surface layer and then rise while saline droplets sink, triggering convection (Rudels and Quadfasel, 1991). The relationship has also been identified in the models from the CORE-II experiments. Danabasoglu et al. (2014) found that models with less sea ice had a salty bias at the surface and hence deeper MLDs.

In the current study, no across-model relationship was found between sea ice extent and deep convection in CMIP5 models. The maximum extent, the seasonal cycle and the variability yielded no significant result. However, we do observe that deep convection follows the winter sea ice edge (blue lines in Fig. 1), in agreement with Danabasoglu et al. (2014).

In fact, the majority of models that do not convect in the Labrador Sea are ice-covered in this region in winter. Bcc-csm1-1, CMCC-CM, CMCC-CMS, both GFDL-ESM2G and GFDL-ESM2M, IPSL-CM5A-LR, IPSL-CM5A-MR, and MIROC-ESM-CHEM have a sea ice cover between Greenland and North America that extends significantly further south and east than in observations (Fig. 1c, g, h, m, n, r, s, u). Similarly, in the GIN seas, the location of deep convection is immediately east of the sea ice. The models which are most ice-covered in the GIN seas, notably bcc-csm1-1 and the three GFDL models, have deep convection more in the east and south than the observations (Fig. 1c, 1, m, n).

The models with the most accurate representation of deep convection, at least the most accurate location, seem to be the ones with the most accurate winter sea ice extent, as was found by Loder et al. (2015) in a subset of six CMIP5 models. In this study, 15 out of the 23 models share only three different sea ice components (Table 1). Seven of them in particular use CICE: ACCESS1-0, CCSM4, CESM1-CAM5, FGOALS-g2, both HadGEM2 models, and NorESM1-M. Although ACCESS1-0 and NorESM1-M convect too far south in the subpolar gyre (Fig. 1b, x), these seven models are amongst the most accurate in this study. Future model intercomparison effort should consider studying the effect of the sea ice model on the ocean. In fact, such is the plan of the upcoming SIMIP (Notz et al., 2016).
The present study does not mean to identify the driving mechanism for deep convection in the North Atlantic in CMIP5 models. In fact, it has proven that such an exercise is not possible with this type of output, and that dedicated modelling exercises should be performed instead. In a final result section, we shall see why they should indeed be performed, i.e. which impacts a misrepresentation of deep convection has on the water column and ocean circulation.

\section{Why inaccurate North Atlantic deep water formation is a problem}

\subsection{Consequences on the water column}

Following de Jong et al. (2009), Fig. 2 shows the acrossmodel relationship between mean MLD and water property biases at two depth ranges representative of the North Atlantic deep waters in the subpolar gyre. We find no consistent significant relationship between the density bias and the MLD. For example, the models with the deepest MLD are not the densest. In SG in both layers (Fig. 2a, b), models with the smallest biases tend to be those with a mean MLD deeper than $2000 \mathrm{~m}$, although bcc-csm1-1, FGOALS-g2 and GISS-E2-R are notable exceptions, with biases larger than $0.2 \mathrm{~kg} \mathrm{~m}^{-3}$. As was already the case in CMIP3 models (de Jong et al., 2009), there is no clear relationship between the water column density and deep convection, but there is a relationship with temperature in the subpolar gyre (Fig. 2c, d). At both depth levels, the deeper the mean mixed layer, the warmer the model. The relationship is the strongest below $2000 \mathrm{~m}(R=0.59$, Fig. $2 \mathrm{~d})$, where the temporal spread in the temperature values is also lower. As was to be expected in a region where salinity dominates the density signal, the salinity biases resemble the density biases (Fig. 2e, f). As such, no relationship is found between the salinity and the MLD in the subpolar gyre.

Similarly, in the GIN seas, the models that are the most accurate in density seem to correspond to deep mixed layers (Fig. 3a, b), with bcc-csm1-1 being again an exception. In the GIN seas, no significant relationship could be found between the temperature and the MLD, at either depth (Fig. 3c, d). It can be noted in particular that the models with the warmest temperature biases do not have much in common in the GIN seas (Fig. 1): FGOALS-g2 has shallow convection over an extended area, GFDL-CM3 convects to a moderate depth in a region too far south and east, and MIROC-ESM-CHEM convects far too deep but at the correct location. A similar result is found for salinity biases in the GIN seas (Fig. 3e, f). There is no significant across-model relationship between MLD and salinity biases, and the most extreme biases are encountered for similar MLD. FGOALS-g2, the saltiest, and CNRM-CM5, the freshest, both have a mean MLD of approximately $1000 \mathrm{~m}$ (Fig. 3e). 

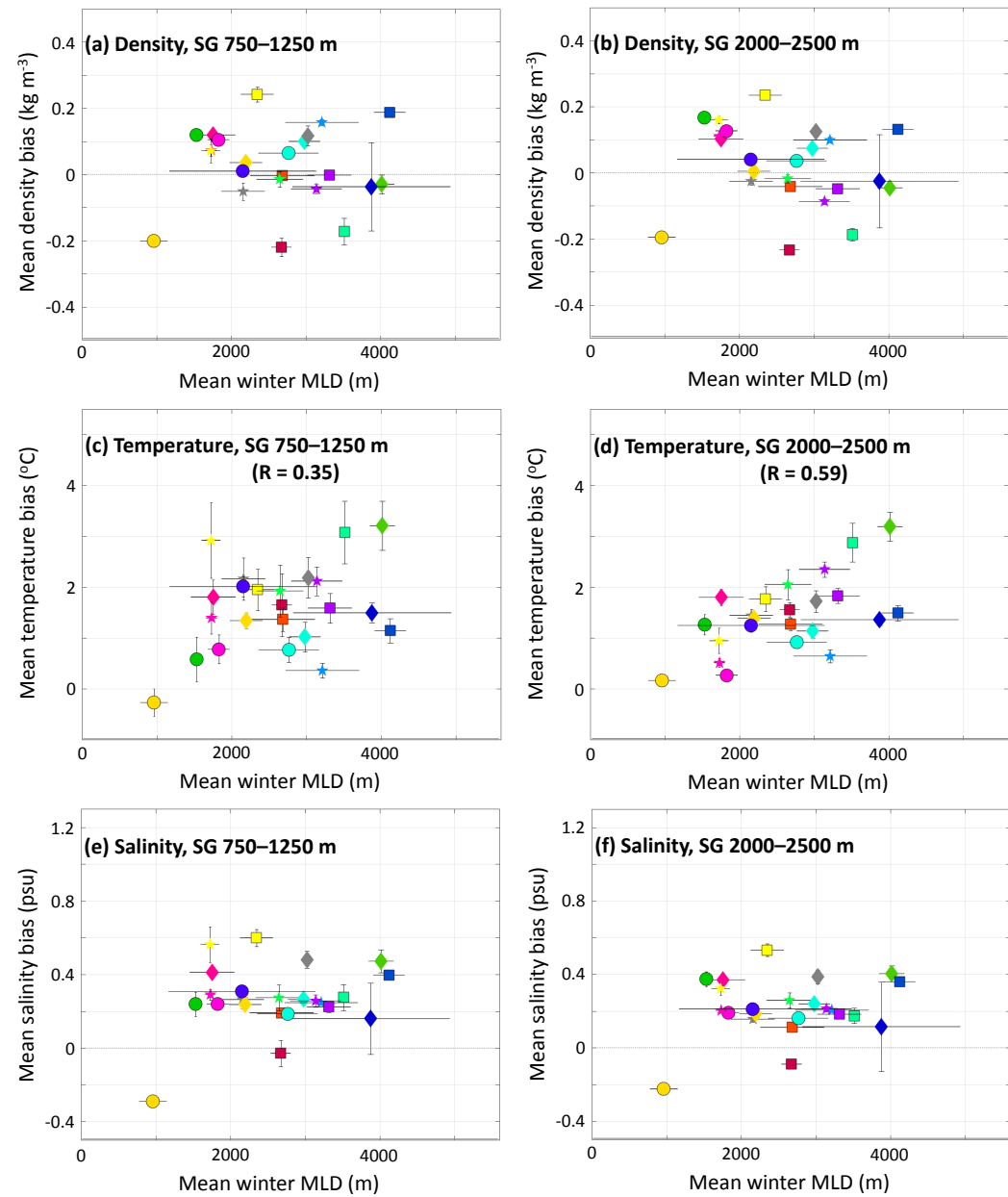

* ACCESS1-0

- bcc-csm1-1

- CanESM2

- CCSM4

* CESM1-CAM5

- CMCC-CM

CMCC-CMS

- CNRM-CM5

CSIRO-Mk3-6-0

$\square$ FGOALS-g2

- GFDL-CM3

- GFDL-ESM2G

* GFDL-ESM2M

$\square$ GISS-E2-R

$\checkmark$ HadGEM2-CC

- HadGEM2-ES

$\star$ IPSL-CM5A-LR

- IPSL-CM5A-MR

- MIROC5

- MIROC-ESM-CHEM

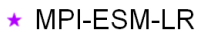

- MPI-ESM-MR

- NorESM1-M

Figure 2. Across-model relationship between the 20-year mean density (a, b), temperature (c, d) and salinity (e, f) bias at the two depth levels representative of NADW (columns) and the 20-year mean winter MLD, in the subpolar gyre SG.

It can be noted that the majority of models have relatively accurate NADW densities at both depths: 13 models are within $0.1 \mathrm{~kg} \mathrm{~m}^{-3}$ of the observations in the SG area (Fig. 2a, b), compared to 17 in the GIN seas (Fig. 3a, b). In fact, most models have a warm and salty bias in both seas (Figs. 2 and 3), but those compensate in density.

In summary, dense water formation is not associated with specific density biases, and the only significant correlation is linked to deep warm biases. To explain this seemingly counter-intuitive finding, we assess using Fig. 4 how the temperature, shown in panel (a), and density, shown in panel (b), are reorganised from month to month through the water column, and show only one model. Each year, deep convection occurs at two times (Fig. 4a):

- first, a warming from the surface, where the warming is the strongest, to approximately $500 \mathrm{~m}$ depth

- then, when the MLD is maximum, a cooling from the surface to a certain depth, and a warming below that depth.
For the events with very deep MLD such as those of 1987 to 1990 and 1993 in Fig. 4, the cooling happens through most of the ML, whereas during shallower events the cooling is limited to the top $500 \mathrm{~m}$ of the water column. In fact, during deep convection, heat is merely reorganised through the water column.

Density does increase during deep convection events (Fig. 4b), but also decreases as deep convection is triggered and in the months before. In agreement with the temperature results, it also decreases during deep convection at the depth levels where temperature increases. In fact, in the subpolar gyre in CMIP5 models, deep convection allows the mixing through the water column of the comparatively warm and salty pool that sits around $500 \mathrm{~m}$. Hence, deep convection is associated with a warming of the deep waters, but like in CMIP3 models this warming is compensated for by salinity so that there is no consensus regarding density (de Jong et al., 2009). 

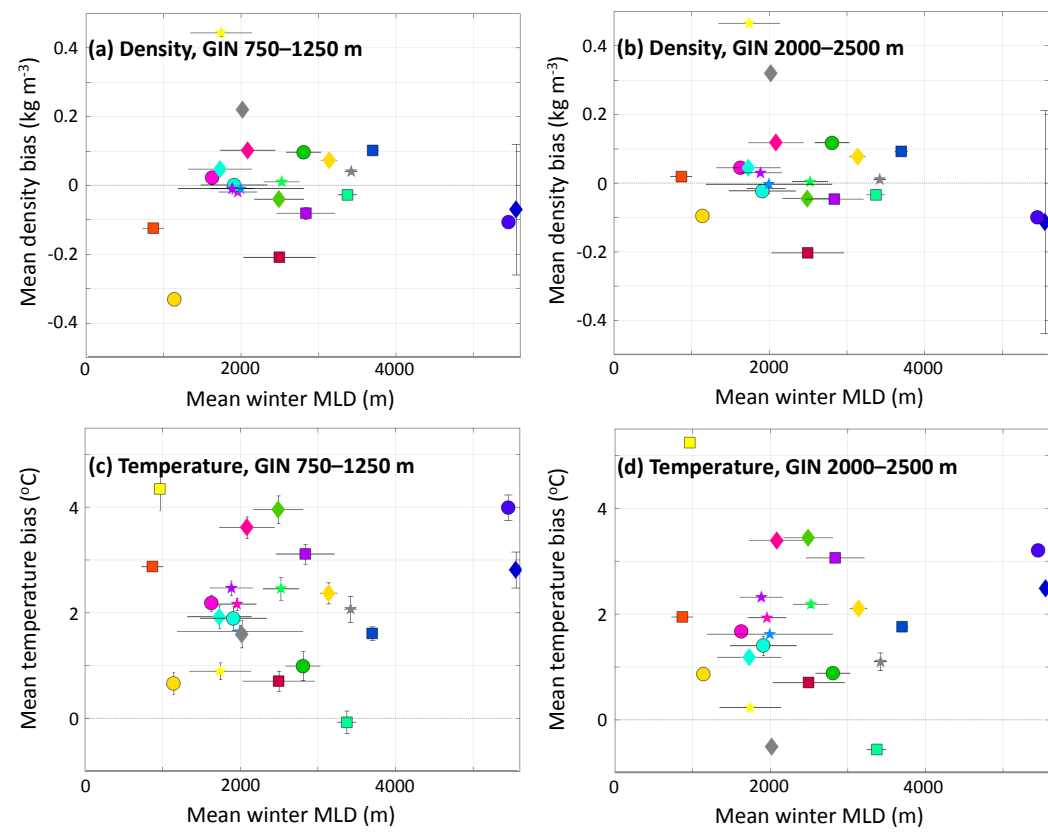

* ACCESS1-0

- bcc-csm1-1

- CanESM2

- CCSM4

* CESM1-CAM5

- CMCC-CM

CMCC-CMS

- CNRM-CM5

CSIRO-Mk3-6-0

- FGOALS-g2

-

GFDL-CM3

- GFDL-ESM2G

* GFDL-ESM2M

$\square$ GISS-E2-R

$\checkmark$ HadGEM2-CC

- HadGEM2-ES

* IPSL-CM5A-LR
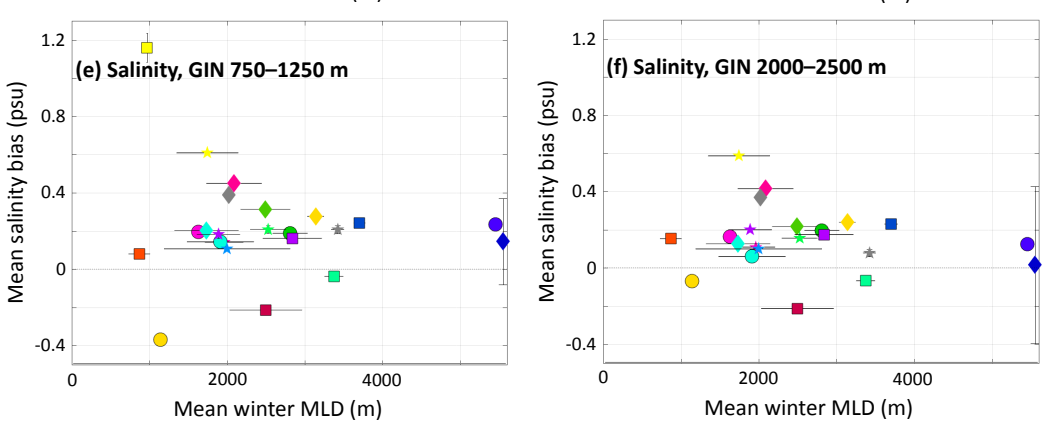

- IPSL-CM5A-MR

- MIROC5

- MIROC-ESM-CHEM

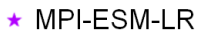

- MPI-ESM-MR

- NorESM1-M

Figure 3. Same as Fig. 2 but for the GIN seas.

\subsection{Consequences on the AMOC and heat export to the Arctic}

In CCSM4, Jahn and Holland (2013) found that less deep convection in the North Atlantic leads to a reduced AMOC. Similarly, in CORE-II experiments, deep mixed layers were associated with large AMOC (Danabasoglu et al., 2014). In the current paper, no across-CMIP5 model relationship was found between the mean winter MLD or volume of deep convection in either region or the AMOC.

This lack of a result was actually not that surprising. In the real North Atlantic, the AMOC is the result of the combined effects of both deep convection regions (Yashayaev, 2007). Moreover, there is a lag between deep convection and the subsequent AMOC strength (Jahn and Holland, 2013). We evaluated such a lag on a subset of 14 CMIP5 models for which we could obtain 100-year pre-industrial control runs (Fig. 5). The majority of these models exhibit a significant correlation with the AMOC when deep convection in the gyre lags by 0 to 2 years before (Fig. $5, y$ axis). There are two maxima, associated with a lag in the GIN seas of 0 to 1 year, but also 14 years before the AMOC (Fig. 5, $x$ axis).

The mechanism linking deep water formation in both regions, the AMOC and poleward heat transport has been tested on several previous occasions using coupled models (e.g. Delworth et al., 1993; Menary et al., 2012; Lohmann et al., 2014). To the best of our knowledge, the most extensive such study was conducted by Ba et al. (2014) and included multi-centennial runs of 10 coupled models. They found that for most models, deep convection was associated with subsequent AMOC with a lag of a year in the SG and 10 years in the GIN seas; our results are consistent with their findings. The large range of values associated with the GIN seas' deep convection could be due to the wrong representation of overflows, caused by the too-coarse resolutions of the models (Jungclaus et al., 2013). This issue is known, and hence possible solutions such as pipe parameterisations that artificially transport the water undisturbed down an overflow area have been designed (Danabasoglu et al., 2010) and are expected to lead to better representations of the AMOC in future CMIPs. 

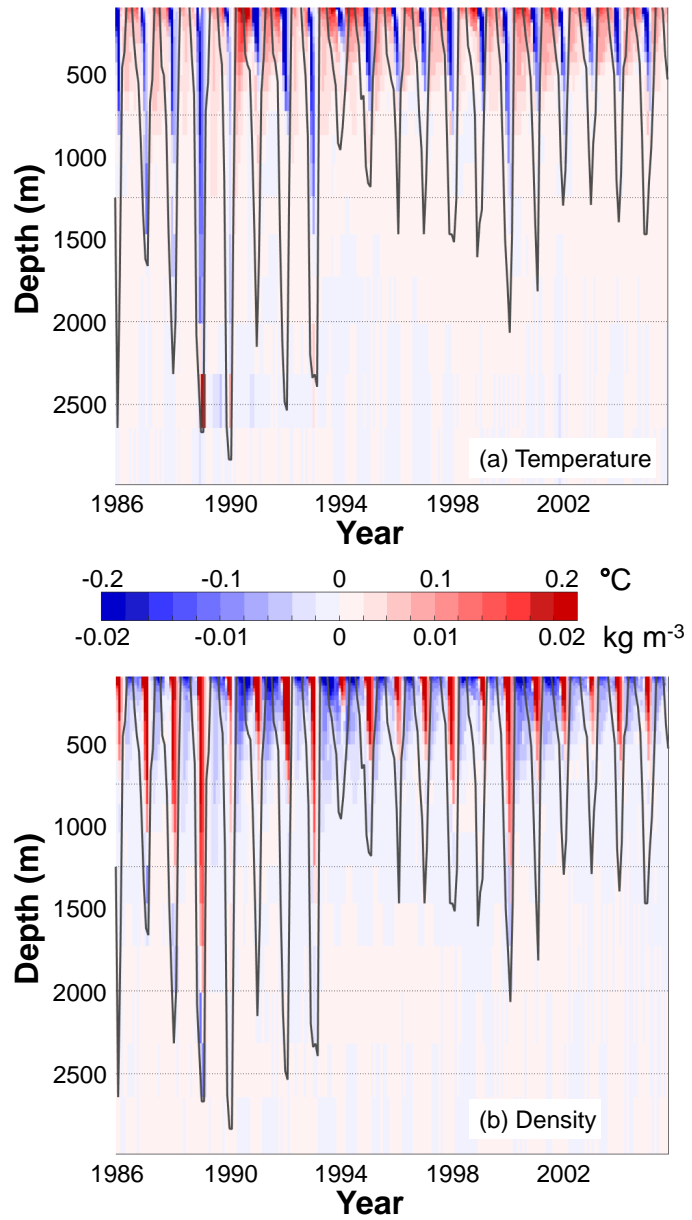

Figure 4. For only one model, CanESM2, Hovmöller diagram showing the difference from 1 month to the next of the temperature (a) and density (b) profiles with depth in the subpolar gyre. Dark grey line represents the SG mixed layer depth. Black dotted vertical lines highlight the depth levels representative of NADW: $750,1250,2000$ and $2500 \mathrm{~m}$.

So there is a relationship between deep convection and the strength of the AMOC in CMIP5 models. In other models, the stronger the AMOC, the more heat is sent northwards to the Arctic (e.g. Jahn and Holland, 2013; Danabasoglu et al., 2014). We find the same result in CMIP5 models (Fig. 6). The mean heat flux through the Fram Strait is not clearly related to the mean volume of deep convection in the subpolar gyre (Fig. 6a), the GIN seas (Fig. 6b), or the sum of the two (Fig. 6c). But there is a strong robust across-model relationship between the AMOC and the heat flux: the stronger the AMOC, the more heat is exported to the Arctic through the Fram Strait (Fig. 6d).

In most CMIP5 models, there is a dynamical relationship between deep water formation and the AMOC. There is also a relationship between the AMOC and the heat export to the Arctic. So not only the volumes but also the temporal variability of deep convection need to be better represented to

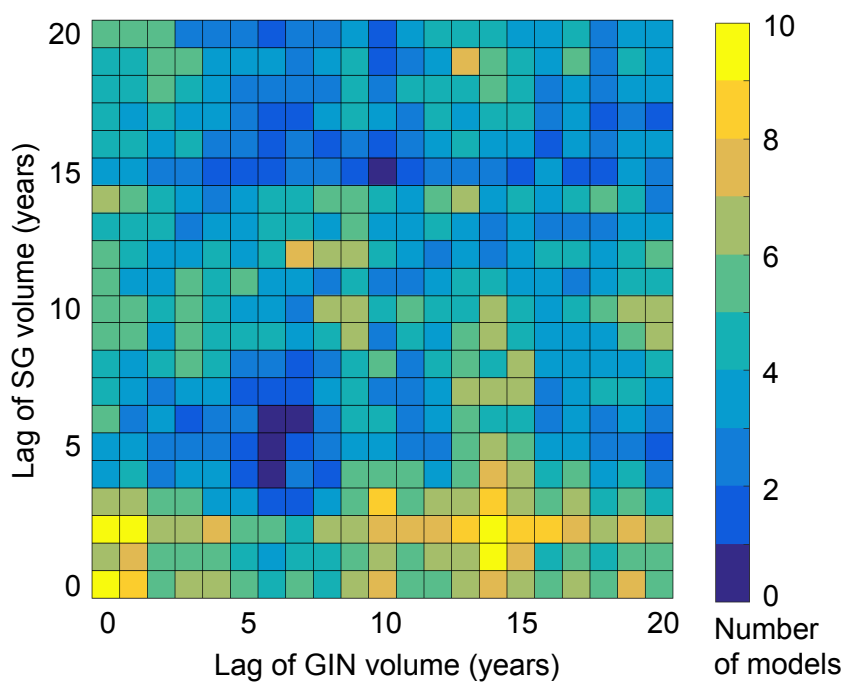

Figure 5. Number of models out of the 14-model subset where a significant correlation was found between the AMOC and the sum of the volumes of deep convection SG + GIN, for different lags of SG (vertical) and GIN (horizontal); deep convection before AMOC.

correctly model the amount of oceanic heat that enters the Arctic through the Fram Strait.

\section{Conclusions}

CMIP5 models have improved their representation of deep convection in the North Atlantic compared to CMIP3 models (de Jong et al., 2009). Nearly half of them convect at the correct location, and a third of them with some variability as do the observations. The rest convects too often, too deep, and too far south in the subpolar gyre (Fig. 1). The cause for deep convection bias is model-dependent. The depth is linked to stratification and buoyancy forcings for more than half of the models (Table 2), as the area and location are to the sea ice extent (Fig. 1). In particular, models with the same sea ice component, CICE, seem to have the most accurate sea ice extent in the subpolar gyre and Greenland-Iceland-Norwegian seas, and the most accurate deep convection there. Surprisingly, some models exhibited counter-intuitive relationships, contrary to observations, between freshwater fluxes, local buoyancy forcings and mixed layer depth (Table 2). Dedicated studies should be performed by the modelling community to assess the causes of such spurious relationships, investigating the role of the vertical mixing parameterisation (FoxKemper et al., 2011) or the representation of the Canadian Archipelago (Komuro and Hasumi, 2005) for example. We found that deep convection leads to a redistribution of heat through the water column, so that the models with the most intense convection are in fact the warmest (Fig. 2); nothing consistent was found regarding density because of salinity mixing. Finally, the stronger the deep convection in CMIP5 

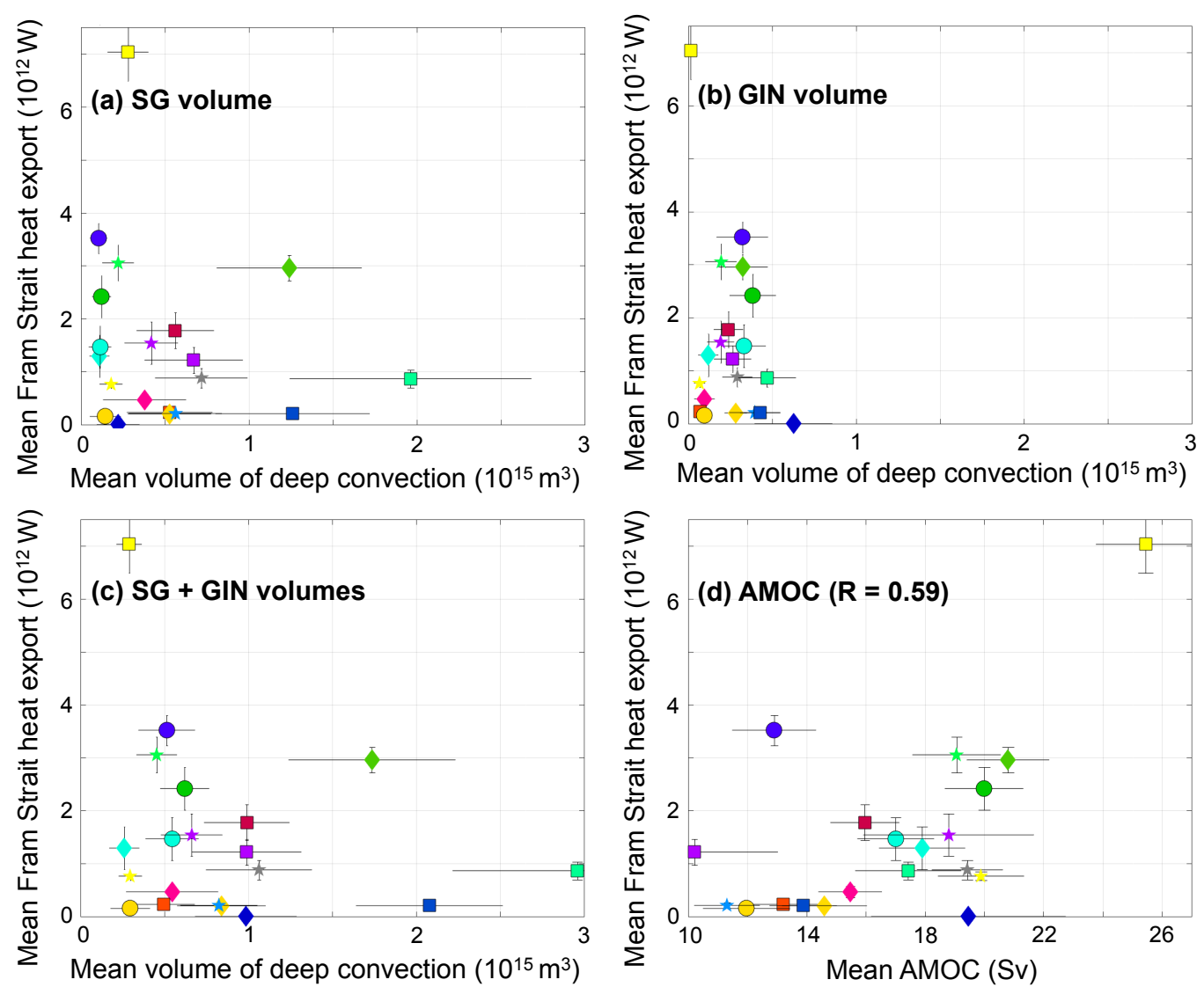

\begin{tabular}{|c|c|c|}
\hline $\begin{array}{l}\text { ACCESS1-0 } \\
\text { bcc-csm1-1 } \\
\text { CanESM2 } \\
\text { CCSM4 } \\
\star \text { CESM1-CAM5 } \\
\text { CMCC-CM } \\
\text { CMCC-CMS } \\
\text { CNRM-CM5 }\end{array}$ & $\begin{aligned} & \text { CSIRO-Mk3-6-0 } \\
& \text { FGOALS-g2 } \\
& \text { GFDL-CM3 } \\
& \text { GFDL-ESM2G } \\
& \star \text { GFDL-ESM2M } \\
& \text { GISS-E2-R } \\
& \text { HadGEM2-CC }\end{aligned}$ & $\begin{array}{l}\text { HadGEM2-ES } \\
\text { ^ IPSL-CM5A-LR } \\
\text { IPSL-CM5A-MR } \\
\text { MIROC5 } \\
\text { MIROC-ESM-CHEM } \\
\text { ^ MPI-ESM-LR } \\
\text { MPI-ESM-MR } \\
\text { MorESM1-M }\end{array}$ \\
\hline
\end{tabular}

Figure 6. Across-model relationship between the 20-year mean heat export to the Arctic through the Fram Strait and the 20-year mean (a) volume of deep convection in SG; (b) volume of deep convection in GIN; (c) total volume of deep convection SG + GIN; (d) AMOC.

models, the stronger their Atlantic Meridional Overturning Circulation 2 years later (Fig. 5), and in turn the stronger the heat export to the Arctic (Fig. 6).

These results should be taken as they are: correlations, not full dynamical studies. Dedicated experiments, performed on an ocean at rest, over centuries, would be needed to assess what triggers deep convection in each model, and would probably require output at a higher time resolution than monthly means. Similarly, the relationship between the choice of a sea ice model and the accuracy of deep water formation would need a proper sea ice MIP to be checked. Fortunately, a SIMIP exercise is indeed planned for CMIP6 (Notz et al., 2016). Only then can we accurately assess the heat transport to the Arctic and its future change, and hence predict the demise of Arctic sea ice and Greenland floating glaciers.
Data availability. The CMIP5 data are available at http://www. ipcc-data.org/sim/gcm_monthly/AR5/Reference-Archive.html.

The climatological data for the mixed layer depth are available at http://www.ifremer.fr/cerweb/deboyer/mld/home.php, and those of the ocean temperature and salinity at http://www.nodc.noaa.gov/OC5/WOA09/pr_woa09.html.

Sea ice concentration observations are available at http://www.metoffice.gov.uk/hadobs/hadisst/.

Competing interests. The author declares that they have no conflict of interest.

Acknowledgements. We acknowledge the World Climate Research Programme's Working Group on Coupled Modelling, which is responsible for CMIP, and we thank the climate modelling groups (whose models are listed in Table 1 of this paper) for producing 
and making available their model output. The author would like to thank Matthew Palmer of UK Met Office for his willingness to share model outputs (that were eventually not used for this paper) and Anna Wåhlin for advice and helpful comments, as well as Peter R. Gent and an anonymous reviewer, whose suggestions notably improved the quality of this paper.

Edited by: Matthew Hecht

Reviewed by: Peter R. Gent and one anonymous referee

\section{References}

Aagaard, K. and Carmack, E. C.: The role of sea ice and other fresh water in the Arctic circulation, J. Geophys. Res.-Oceans, 94, 14485-14498, https://doi.org/10.1029/JC094iC10p14485, 1989.

Ba, J., Keenlyside, N. S., Latif, M., Park, W., Ding, H., Lohmann, K., Mignot, J., Menary, M., Otterå, O. H., Wouters, B., Salas y Melia, D., Oka, A., Bellucci, A., and Volodin, E.: A multi-model comparison of Atlantic multidecadal variability, Clim. Dynam., 43, 2333-2348, 2014.

Böning, C. W., Scheinert, M., Dengg, J., Biastoch, A., and Funk, A.: Decadal variability of subpolar gyre transport and its reverberation in the North Atlantic overturning, Geophys. Res. Lett., 33, L21S01, https://doi.org/10.1029/2006GL026906, 2006.

Carman, J. C. and McClean, J. L.: Investigation of IPCC AR4 coupled climate model North Atlantic mode water formation, Ocean Model., 40, 14-34, https://doi.org/10.1016/j.ocemod.2011.07.001, 2011.

Cheng, W., Chiang, J. C. H., and Zhang, D.: Atlantic Meridional Overturning Circulation (AMOC) in CMIP5 Models: RCP and historical simulations, J. Climate, 26, 7187-7197, https://doi.org/10.1175/JCLI-D-12-00496.1, 2013.

Danabasoglu, G., Large, W. G., and Briegleb, B. P.: Climate impacts of parameterized Nordic Sea overflows, J. Geophys. Res.Oceans, 115, C11005, https://doi.org/10.1029/2010JC006243, 2010.

Danabasoglu, G., Yeager, S. G., Bailey, D., Behrens, E., Bentsen, M., Bi, D., Biastoch, A., Böning, C., Bozec, A., Canuto, V. M., and Cassou, C.: North Atlantic simulations in coordinated ocean-ice reference experiments phase II (COREII) - Part I: mean states, Ocean Model., 73, 76-107, https://doi.org/10.1016/j.ocemod.2013.10.005, 2014.

de Boyer Montégut, C., Madec, G., Fisher, A. S., Lazar, A., and Iudicone, D.: Mixed layer depth over the global ocean: An examination of profile data and a profilebased climatology, J. Geophys. Res., 109, C12003, https://doi.org/10.1029/2004JC002378, 2004.

de Jong, M. F., Drijfhout, S. S., Hazeleger, W., van Aken, H. M., and Severijns, C. A.: Simulations of hydrographic properties in the northwestern North Atlantic Ocean in coupled climate models, J. Climate, 22, 1767-1786, 2009.

Delworth, T., Manabe, S., and Stouffer, R. J.: Interdecadal variations of the thermohaline circulation in a coupled ocean-atmosphere model, J. Climate, 6, 1993-2011, https://doi.org/10.1175/15200442(1993)006<1993:IVOTTC>2.0.CO;2, 1993.

Delworth, T. L., Broccoli, A. J., Rosati, A., Stouffer, R. J., Balaji, V., Beesley, J. A., Cooke, W. F., Dixon, K. W., Dunne, J., Dunne, K.
A., and Durachta, J. W.: GFDL's CM2 Global Coupled Climate Models - Part I: Formulation and simulation characteristics, J. Climate, 19, 643-674, 2006.

Drijfhout, S., Hazeleger, W., Selten, F., and Haarsma, R.: Future changes in internal variability of the Atlantic Meridional Overturning Circulation, Clim. Dynam., 30, 407-419, 2008.

Eyring, V., Bony, S., Meehl, G. A., Senior, C. A., Stevens, B., Stouffer, R. J., and Taylor, K. E.: Overview of the Coupled Model Intercomparison Project Phase 6 (CMIP6) experimental design and organization, Geosci. Model Dev., 9, 1937-1958, https://doi.org/10.5194/gmd-9-1937-2016, 2016.

Fichefet, T. and Maqueda, M. A. M.: Sensitivity of a global sea ice model to the treatment of ice thermodynamics and dynamics, J. Geophys. Res., 102, 12609-12646, 1997.

Flato, G., Marotzke, J., Abiodun, B., Braconnot, P., Chou, S. C., Collins, W. J., Cox, P., Driouech, F., Emori, S., Eyring, V., and Forest, C.: Climate Change 2013: The Physical Science Basis, Contribution of Working Group I to the Fifth Assessment Report of the Intergovernmental Panel on Climate Change, Evaluation of Climate Models, Cambridge University Press, Cambridge, UK, New York, NY, USA, 2013.

Fox-Kemper, B., Danabasoglu, G., Ferrari, R., Griffies, S. M., Hallberg, R. W., Holland, M. M., Maltrud, M. E., Peacock, S., and Samuels, B. L.: Parameterization of mixed layer eddies, III: Implementation and impact in global ocean climate simulations, Ocean Model., 39, 61-78, 2011.

Griffies, S. M., Danabasoglu, G., Durack, P. J., Adcroft, A. J., Balaji, V., Böning, C. W., Chassignet, E. P., Curchitser, E., Deshayes, J., Drange, H., Fox-Kemper, B., Gleckler, P. J., Gregory, J. M., Haak, H., Hallberg, R. W., Heimbach, P., Hewitt, H. T., Holland, D. M., Ilyina, T., Jungclaus, J. H., Komuro, Y., Krasting, J. P., Large, W. G., Marsland, S. J., Masina, S., McDougall, T. J., Nurser, A. J. G., Orr, J. C., Pirani, A., Qiao, F., Stouffer, R. J., Taylor, K. E., Treguier, A. M., Tsujino, H., Uotila, P., Valdivieso, M., Wang, Q., Winton, M., and Yeager, S. G.: OMIP contribution to CMIP6: experimental and diagnostic protocol for the physical component of the Ocean Model Intercomparison Project, Geosci. Model Dev., 9, 3231-3296, https://doi.org/10.5194/gmd-9-32312016, 2016.

Huang, C., Qiao, F., and Dai, D.: Evaluating CMIP5 simulations of mixed layer depth during summer, J. Geophys. Res.-Oceans, 119, 2568-2582, 2014.

Hunke, E. C. and Lipscomb, W. H.: CICE: the Los Alamos sea ice model user's manual, version 4, Tech. rep., Los Alamos National Laboratory, 2008.

Jahn, A. and Holland, M. M.: Implications of Arctic sea ice changes for North Atlantic deep convection and the meridional overturning circulation in CCSM4 CMIP5 simulations, Geophys. Res. Lett., 40, 1206-1211, https://doi.org/10.1002/grl.50183, 2013.

Jungclaus, J. H., Haak, H., Latif, M., and Mikolajewicz, U.: ArcticNorth Atlantic interactions and multidecadal variability of the meridional overturning circulation, J. Climate, 18, 4013-4031, https://doi.org/10.1175/JCLI3462.1, 2005.

Jungclaus, J. H., Fischer, N., Haak, H., Lohmann, K., Marotzke, J., Matei, D., Mikolajewicz, U., Notz, D., and Storch, J. S.: Characteristics of the ocean simulations in the Max Planck Institute Ocean Model (MPIOM) the ocean component of the MPI Earth system model, J. Adv. Model. Earth Sy., 5, 422-446, https://doi.org/10.1002/jame.20023, 2013. 
Killworth, P. D.: Deep convection in the World Ocean, Rev. Geophys. Space Phys., 21, 1-26, https://doi.org/10.1029/RG021i001p00001, 1983.

Komuro, Y. and Hasumi, H.: Intensification of the Atlantic deep circulation by the Canadian Archipelago throughflow, J. Phys. Ocean., 35, 775-789, https://doi.org/10.1175/JPO2709.1, 2005.

Locarnini, R. A., Mishonov, A. V., Antonov, J. I., Boyer, T. P., Garcia, H. E., Baranova, O. K., Zweng, M. M., Paver, C. R., Reagan, J. R., Johnson, D. R., Hamilton, M., and Seidov, D.: World Ocean Atlas 2013, Volume 1: Temperature, Tech. rep., NOAA Atlas Nesdis, 2013.

Loder, J., van der Baaren, A., and Yashayaev, I.: Climate comparisons and change projections for the Northwest Atlantic from six CMIP5 models, Atmos. Ocean, 53, 529-555, 2015.

Lohmann, K., Jungclaus, J. H., Matei, D., Mignot, J., Menary, M., Langehaug, H. R., Ba, J., Gao, Y., Otterå, O. H., Park, W., and Lorenz, S.: The role of subpolar deep water formation and Nordic Seas overflows in simulated multidecadal variability of the Atlantic meridional overturning circulation, Ocean Sci., 10, 227241, https://doi.org/10.5194/os-10-227-2014, 2014.

Lozier, M. S., Leadbetter, S., Williams, R. G., Roussenov, V., Reed, M. S. C., and Moore, N. J.: The spatial pattern and mechanisms of heat-content change in the North Atlantic, Science, 319, 800803, https://doi.org/10.1126/science.1146436, 2008.

Marshall, J. and Schott, F.: Open-ocean convection: Observations, theory and models, Rev. Geophys., 37, 1-64, https://doi.org/10.1029/98RG02739, 1999.

Martin, T., Park, W., and Latif, M.: Multi-centennial variability controlled by Southern Ocean convection in the Kiel Climate Model, Clim. Dynam., 40, 2005-2022, https://doi.org/10.1007/s00382012-1586-7, 2013.

Menary, M., Park, W., Lohmann, K., Vellinga, M., Palmer, M., Latif, M., and Jungclaus, J.: A multimodel comparison of centennial Atlantic meridional overturning circulation variability, Clim. Dynam., 38, 2377-2388, 2012.

Notz, D., Jahn, A., Holland, M., Hunke, E., Massonnet, F., Stroeve, J., Tremblay, B., and Vancoppenolle, M.: The CMIP6 SeaIce Model Intercomparison Project (SIMIP): understanding sea ice through climate-model simulations, Geosci. Model Dev., 9, 3427-3446, https://doi.org/10.5194/gmd-9-3427-2016, 2016.

Oka, A., Hasumi, H., Okada, N., and Suzuki, T. T., and Suzuki, T.: Deep convection seesaw controlled by freshwater transport through the Denmark Strait, Ocean Model., 15, 157-176, https://doi.org/10.1016/j.ocemod.2006.08.004, 2006.

Polyakov, I. V., Timokhov, L. A., Alexeev, V. A., Bacon, S., Dmitrenko, I. A., Fortier, L., Frolov, I. E., Gascard, J. C., Hansen, E., Ivanov, V. V., and Laxon, S.: Arctic Ocean warming contributes to reduced polar ice cap, J. Phys. Oceanogr., 40, 27432756, https://doi.org/10.1175/2010JPO4339.1, 2010.

Rayner, N. A., Parker, D. E., Horton, E. B., Folland, C. K., Alexander, L. V., Rowell, D. P., Kent, E. C., and Kaplan, A.: Global analyses of sea surface temperature, sea ice, and night marine temperature since the late nineteenth century, J. Geophys. Res., 108, 4407, https://doi.org/10.1029/2002JD002670, 2003.
Rudels, B. and Quadfasel, D.: Convection and deep water formation in the Arctic Ocean-Greenland Sea system, J. Marine Syst., 2, 435-450, https://doi.org/10.1016/0924-7963(91)90045-V, 1991.

Sabine, C. L., Feely, R. A., Gruber, N., Key, R. M., Lee, K., Bullister, J. L., Wanninkhof, R., Wong, C., Wallace, D. W., Tilbrook, B., and Millero, F. J.: The oceanic sink for anthropogenic $\mathrm{CO}_{2}$, Science, 305, 367-371, https://doi.org/10.1126/science.1097403, 2004.

Schmittner, A. and Lund, D. C.: Early deglacial Atlantic overturning decline and its role in atmospheric $\mathrm{CO}_{2}$ rise inferred from carbon isotopes $\left(\delta^{13} \mathrm{C}\right)$, Clim. Past, 11, 135-152, https://doi.org/10.5194/cp-11-135-2015, 2015.

Spielhagen, R. F., Werner, K., Sørensen, S. A., Zamelczyk, K., Kandiano, E., Budeus, G., Husum, K., Marchitto, T. M., and Hald, M.: Enhanced Modern Heat Transfer to the Arctic by Warm Atlantic Water, Science, 331, 450-453, https://doi.org/10.1126/science.1197397, 2011.

Straneo, F. and Heimbach, P.: North Atlantic warming and the retreat of Greenland's outlet glaciers, Nature, 504, 36-43, https://doi.org/10.1038/nature12854, 2013.

Taylor, K. E., Stouffer, R. J., and Meehl, G. A.: An overview of CMIP5 and the experiment design, B. Am. Meteorol. Soc., 93, 485-498, https://doi.org/10.1175/BAMS-D-11-00094.1, 2012.

Treguier, A. M., Theetten, S., Chassignet, E. P., Penduff, T., Smith, R., Talley, L., Beismann, J. O., and Böning, C.: The North Atlantic Subpolar Gyre in Four High-Resolution Models, J. Phys. Oceanogr., 35, 757-774, https://doi.org/10.1175/JPO2720.1, 2005.

Våge, K., Pickart, R. S., Thierry, V., Reverdin, G., Lee, C. M., Petrie, B., Agnew, T. A., Wong, A., and Ribergaard, M. H.: Surprising return of deep convection to the subpolar North Atlantic Ocean in winter 2007-2008, Nat. Geosci., 2, 67-72, https://doi.org/10.1038/ngeo382, 2009.

Weaver, A. J., Bitz, C. M., Fanning, A. F., and Holland, M. M.: Thermohaline circulation: High-latitude phenomena and the difference between the Pacific and Atlantic, Annu. Rev. Earth Pl. Sc., 27, 231-285, https://doi.org/10.1146/annurev.earth.27.1.231, 1999.

Yashayaev, I.: Hydrographic changes in the Labrador Sea, 1960-2005, Prog. Oceanogr., 73, 242-276, https://doi.org/10.1016/j.pocean.2007.04.015, 2007.

Zweng, M. M., Reagan, J. R., Antonov, J. I., Locarnini, R. A., Mishonov, A. V., Boyer, T. P., Garcia, H. E., Baranova, O. K., Johnson, D. R., Seidov, D., and Biddle, M. M.: World Ocean Atlas 2013, Volume 2: Salinity, Tech. rep., NOAA Atlas Nesdis, 2013. 